\title{
Üniversite Öğrencilerinin Girişimcilik Eğilimlerinin Belirlenmesi: OMÜ Ziraat Fakültesi
} Örneği

\author{
Hilal Demir (D) Kürşat Demiryürek (D) \\ Ondokuz Mayıs Üniversitesi, Ziraat Fakültesi Tarım Ekonomisi Bölümü, Samsun \\ 凹: hilaldemir55@gmail.com
}

\section{ÖZET}

Son yıllarda yaşanan küresel rekabet ve teknolojide meydana gelen hızlı değişim makro ekonomik politikalar yanında, girişimcilik faaliyetine olan ilgiyi de artırmıştır. Yapılan araştırmalar dikkate alındığında, Türkiye'de çalışan nüfusun büyük bir bölümünün kendi işini kurmayı hayal ettiği bilinmektedir. Bu noktada girişimci risk alabilen, ihtiyaç duyulan kaynakları bir araya getirme yetisine sahip, başarıyı elde edebilmek için çevresine bakmasını ve ihtiyaçlarını görmesini bilen, yeniliklere açık biri olarak da tanımlanabilir. Araştırmanın amacı, Ondokuz Mayıs Üniversitesi Ziraat Fakültesinin farklı bölümlerinde girişimcilik dersini alan son sınıf öğrencilerinin, girişimcilik eğitimiyle birlikte yenilikçi, risk alma eğilimi, kendine güven, başarı ihtiyacı, belirsizliğe karşı tolerans ve kontrol odağı gibi kişilik özelliklerinin öğretilmeye çalışılmasına yönelik gerçekleştirilmiştir. Bu çalışmayla birlikte öğrencilerde var olan girişimcilik potansiyelinin ortaya çıkarılması amaçlanmaktadır. Araştırmanın evrenini Ondokuz Mayıs Üniversitesi Ziraat Fakültesinde öğrenim gören öğrenciler örneklemini ise, Ziraat Fakültesinde farklı bölümlerde okuyan ve girişimcilik dersini alan, 76 son sinıf öğrencisi oluşturmaktadır. Araştırma grubu oluşturulurken, fakültedeki tüm bölümleri temsilen gayeli olarak, kitledeki tüm birimlere ulaşılmasıyla tam sayım yapılmıştır. Araştırma kapsamındaki öğrencilerin 32'si kız, 44’ü ise erkektir. Araştırmanın amacına yönelik mevcut bilgiler, alan yazınıla birlikte sistematik bir şekilde verilmiştir. Verilerin çözüm ve yorumlanmasında ise korelasyon analizine başvurulmuştur. Elde edilen bulgular analiz edildiğinde, Ziraat Fakültesinin son sınıfında öğrenim gören öğrencilerin girişimcilik özellikleri ile girişimcilik faaliyeti arasında istatistikî açıdan anlamlı bir ilişki olduğu tespit edilmiştir. Bu sonuçlara göre; araştırmaya katılan öğrencilerin girişimcilik özellikleri arttıkça girişimcilik faaliyetlerinin de $\operatorname{arttığı~}$ görülmektedir. Ayrıca girişimcilik özellikleri taşıyan son sınıf öğrencilerinin aynı zamanda önemli düzeyde girişimcilik alanındaki faaliyetlere yatkın olma özelliğine sahip oldukları da söylenebilir. Sonuç olarak, girişimcilik eğiliminin belirlenmesi, potansiyel girişimcilik özelliğine sahip olanların doğru yönlendirilmesi ve iş hayatına kazandırılması ancak girişimcilerin psikolojik ve demografik faktörler ile anlamlı bir ilişki içerisinde olmasıyla gerçekleşebilir.

\author{
Makale Tarihçesi \\ Geliş : 21.10.2018 \\ Kabul : 28.12.2018

Anahtar Kelimeler
Girişimcilik Eğilimi,
Üniversite Öğrencileri,
Girişimcilik Faaliyeti,
Korelâsyon Analizi

Araştırma Makalesi

\section{Determination of Entrepreneurship Tendencies of University Students: The Case of OMU Faculty of Agriculture}

\section{ABSTRACT}

Recent global competition and the rapid change that occurred in technology increased the interest in entrepreneurship activities in addition to macroeconomic policies. When studies conducted are taken into consideration, it is known that a great majority of the population in Turkey dream about starting their own business. Entrepreneurship starts with the drive to start a phenomenon and to perform a

\section{Article History}

Received : 21.10.2018

Accepted : 28.12.2018 
phenomenon. At this point, an entrepreneur can be defined as someone who can take risks, who has the ability to bring the required resources together, who knows to look around and to see the needs in order to reach success and as someone who is open to innovations. The aim of this study was to teach students in their last year who are taking entrepreneurship courses such as innovativeness, tendency for taking risks, self-confidence, need for success, tolerance for uncertainty and focus of control with entrepreneurship education to bring out the existing entrepreneurship potential in students participating in different departments of Ondokuz Mayıs University Faculty of Agriculture characteristics. The universe of the study consists of students studying at Ondokuz Mayıs University Faculty of Agriculture, while the sample consists of 76 last year students who werein different departments of the Faculty of Agriculture taking entrepreneurship courses. While forming the research group, a full count was made to reach all the units in the population to represent all the departments in the faculty. Overall, 32 of the students in the study were female and 44 were male. The existing information about the purpose of the study was given systematically with the literature. Correlation analysis was conducted in the analysis and interpretation of the data was proceeded. When the results found were analyzed, statistically significacy was found between the entrepreneurship characteristics and entrepreneurship activities of the students. According to these results, it can be seen that as the entrepreneurship characteristics of the students who participated in the study increase, their entrepreneurship activities also increase. In addition, last year students who have entrepreneurship characteristics also have a significant tendency for activities in the field of entrepreneurship. As a conclusion, finding out entrepreneurship tendencies, correct guidance of those who have potential entrepreneurship characteristics and leading them to business world can only occur through entrepreneurs' being in a significant relationship with psychological and demographic factors.

\author{
Keywords \\ Entrepreneurship Tendency, \\ University Students, \\ Entrepreneurship Activity, \\ Correlation Analysis
}

\section{Research Article}

To cite: Demiryürek K, Demir H 2018. Üniversite Öğrencilerinin Girişimcilik Eğilimlerinin Belirlenmesi: OMÜ Ziraat Fakültesi Örneği. KSÜ Tar Doğa Derg 21(Özel Sayı) : 168-176, DOI : 10.18016/ ksutarimdoga.vi.472966

\section{GİISŞ}

Girişimcilik kavramı toplumun tüm kesimlerini etkileyen, çalışma hayatına yön veren, sosyal gelişmenin, istihdam yaratmanın ve iktisadi kalkınmanın temel faktörü olarak görülmektedir (Koh, 1996). Girişimcilik, ülke ekonomisinin temel yapı taşlarından biridir. Gerek istihdam yaratmak, gerekse ekonomik platformlarda rekabet üstünlüğü elde ederek refah seviyesini artırmak için önemli bir kavramdır (Ulucan, 2015).

Girişimcilik, bireylerin çalışma hayatlarından itibaren yapmış oldukları organizasyon, firsat tanımlama ve kaynakları da içerisine alan faaliyetlerin tamamını ifade eden bir süreçten oluşmaktadır. Yeni şirketlerin faaliyetlerinde görülen kayda değer artış ve elde edilen sonuçlar girişimciliğe duyulan ilginin nedenleri arasında gösterilebilir. Geçmiş dönemlerde piyasada etkin bir rol üstlenen büyük işletmelerin, günümüz iş şartlarına uyum gösterememesi bu işletmelerin başarılarında gözle görülür bir düşüşe neden olmuştur. Girişimcilik faaliyetinin tekrar gözden geçirilmesine ve girişimciliğe yönelik çabaların artmasında ortaya çıkan bu durum etkili olmuştur (Korkmaz, 2012). Bu noktada özellikle üniversitelere ve eğitim kurumlarına önemli görevler düşmektedir. Son yıllarda yapılan araştırmalardan elde edilen bulgular genç kuşak ile orta kuşak arasında girişimcilik faaliyetini bir meslek olarak ortaya koymaktadır. Bu bağlamda, gençler arasında başarılı girişimcilerin teşvik edilmesi ve bu sayıların artırılması girişimciliğin gelişmesini olumlu yönde etkileyecektir (Özdemir, 2013). Şu an için üniversiteler ekonomiye, insanlığa, toplumun refah düzeyine ve yaşam kalitesine sosyal, ekonomik ve kültürel açıdan geniş perspektifte katkıda bulunmaktadır (Greenspan ve Rosan, 2006).

Girişimcilik, doğuştan bazı yeteneklere sahip olmayı gerektirdiği gibi bazı becerileri de gerekli kılmaktadır. Özellikle girişimcilik ruhuna sahip kişiler başarmaya heveslidir ve yeni fikirler yaratmaya da isteklidirler. 
Girişimci kişiler sıradanlığı sevmez, sürekli çalışmak ve yeni bir şeyler üretme isteği içerisindedirler (Güney, 2008).

$\mathrm{Bu}$ açıklamalar ışı̆̆ında, bir ülkenin ekonomik büyümesi ve yeterli seviyede kalkınabilmesi için iktisadi değeri artıracak, büyümeye ivme kazandıracak, değişen şartlara uyum gösterebilecek girişimcilerin ortaya çıkarılması önemli olmaktadır. Bunun için, girişimcilik potansiyelinin ortaya çıkarılmasında eğitim, en önemli faktörlerden biri olarak görülmektedir.

Girişimcilik eğitimi ise, bireylerin girişimcilik potansiyeline yönelik gizli kalmış bir takım özelliklerinin ortaya çıkarılmasını ve bu özelliklerin farkına varılmasını amaçlamaktadır.

$\mathrm{Bu}$ çalışmada, girişimci adayı olarak düşünülen Ondokuz Mayıs Üniversitesi Ziraat Fakültesi öğrencilerinin mezun olduktan sonra kendi işini kurmak isteyip istememelerine göre girişimcilik adı altında alacakları kararları etkileyen faktörler belirlenmesi amaçlanmıştır. Bu temel amaca ulaşmak için belirlenen alt amaçlar ise şunlardır:

$\checkmark$ Girişimcilik dersi alan 4. Sinıf öğrencilerinin demografik özelliklerinin belirlenmesi,

$\checkmark$ Girişimcilik eğilimleri başlığı altında girişimciliğe yönelik düşünceleri

$\checkmark$ Girişimcilik eğitimi neticesinde ortaya çıkan sonuçların değerlendirilmeye çalışılmasıdır.

Araştırma üç bölümünden oluşmaktadır. Giriş bölümünde girişimcilikle ilgili temel bilgiler verilmektedir. Araştırmanın ikinci bölümünde, araştırmanın tasarımı ve kavramsal boyutu oluşturulmaktadır. Araştırmanın üçüncü ve son bölümlerinde ise, üniversite öğrencilerinin aldıkları girişimcilik eğitiminin sonuçları, elde edilen bulgular ve istatistiksel veriler şeklinde ele alınarak açıklanmaktadır.

\section{KAVRAMSAL ÇERÇEVE ve KAYNAK ÖZETLERİ}

\section{Girişimcilik}

Girişimcilik terimi, Fransızca bir kelimedir ve kökeni kuruluş (enterprise) kelimesine dayanmaktadır (Arıkan, 2004). Yılmaz ve Sünbül (2009) ise girişimciliği; ekonomik fırsatlar oluşturan, bireyler tarafindan ortaya konulan, birey ve toplum için değer oluşturan ve meydana getirdiği yeniliklerle ekonomik sistemde değişikliklere neden olan bir faaliyet olarak açıklamışlardır.

Girişimcilik kavramıyla ilgili literatürde çeşitli tanımlamalara rastlanmış, incelenen çalışmaların her birinde girişimciliğin farklı boyutları ele alınmıştır. Girişimcilik kavramına yönelik yapılan tüm tanımlamalardaki ortak payda girişimciliğin çeşitli fırsatların değerlendirildiği bir süreç olarak ele alınması ve girişimciliğin evrensel bir olguya sahip olmasıdır (Dündar ve Ağca, 2007). Girişimcilik kavramına ilişkin literatürde en sik rastlanan tanımlar ise şu şekildedir:

Girişimcilik; yeni bir işletme kurma veya büyütme, yeni bir mal veya hizmet yaratma çabası içerisinde kar elde etmeyi amaçlayan bir süreç olarak dile getirilmektedir (Bird, 1989).

-Girişimcilik; birey ve toplum için değer yaratan, ekonomik firsatlara yanit veren ya da ekonomik firsatlar yaratan bireyler tarafindan ortaya konulan, getirdiği yeniliklerle ekonomik sistemde değişikliklere neden olan bir süreç olarak ifade edilmektedir (Muzyka ve ark., 1994).

-Girişimcilik; bir firsat elde etmek amaciyla alternatif üretim süreçlerini inceleme ve onların optimizasyonunu gerçekleştirme sürecidir (Lounsbury, 1998).

-Girişimcilik; bir firsatı kovalama ve o fırsatı yakalamak için bir organizasyon yaratma faaliyetidir (Mueller and Thomas, 2000).

Yapılan bu çalışmalar sonucunda girişimcilik kavramının tanımı yapılırken, hemen hemen hepsinde risk alma, yenilik, dinamiklik, esneklik, yaratıcılık ve gelişim odaklı olma gibi faktörlerin etkili olduğu görülmektedir (Korkmaz, 2000).

\section{Girişimcilik Eğilimi}

Girişimcilik kavramı,yeni alternatifler ortaya koyabilen,firsatları fark eden ve bu firsatları pazarlanabilir fikirlere dönüştürebilen, yenilikçi ve gelişimci kişi olarak tanımlanmaktadır (Schumpter,1934; Korkmaz,2012; Akkoç ve ark.,2012). Hisrish (1985) ise girişimciliği, parasal ve kişisel tatmin karşlığında finansal, psikolojik ve sosyal riskleri üstlenerek, gerekli zaman ve çabayı harcayarak, mal ve hizmet yaratma süreci olarak tanımlamıştır. Bir şeyi sevmeye, istemeye veya yapmaya içten yönelme, meyil, temayül, tandans; İnsanoğlunun yaradılıştan medeniliğe eğilimi vardır sözüyle eğilim tanımlanmaktadır(Ataç,1998).

Gelişmiş toplumlarda yükseköğrenim görmüş bireylere "eğitilmeye hazır hale gelmiş kişiler" olarak da bakılmaktadır (Korkmaz, 2012). Girişimcilik, girişimcilerin baştan sona yaptığı faaliyetlerin bütününü ifade eden bir süreçten oluşmaktadır. $\mathrm{Bu}$ doğrultuda üniversitelerin, verdikleri eğitimle öğrencilerin girişimcilik eğilimlerinin farkına varmalarını sağlamalarında önemli bir görevleri oldukları söylenebilir (Yılmaz ve Sünbül, 2009). Girişimcilik eğiliminde asıl önemli olan eğitim faktörünün, üniversitelerde eğitim gören genç nüfusun, girişimci ruhlarının teşvik edilmesi ve girişimciliğe yönelmeleri üzerinde olumlu etkileri olduğu kabul edilmektedir (Wang ve Wong, 2004).

Türkiye'de üniversite okuyan her öğrenciye birer girişimci adayı gözü ile bakmak ve içinde yaşadıkları çevrenin firsatlarını değerlendirerek, karşılarına 
çıkan sorunları fırsatlara çevirerek, yaratıcı yönlerini ortaya koyacak bireyler olarak yetişmelerini sağlamak son derece önem arz etmektedir ( Titiz,1999).

Özdemir (2013), Kırgızistan-Türkiye Manas Üniversitesi öğrencilerinin sosyo-demografik özelliklerinin girişimcilik eğilimleri üzerindeki etkilerini belirlenmiş öğrencilerin sosyo-demografik özelliklerinin girişimcilik eğilimleri üzerindeki etkisi araştırılmıştır. Çalışmanın sonucunda, sosyodemografik özelliklerin; risk almayı, bağımsızlı̆̆ı, özyeterliliği, başarma ihtiyacını, içsel denetim odağını ve yaratıcılığı etkilediği bulgusuna ulaşılmıştır. $\mathrm{Bu}$ açıdan potansiyel girişimcileri belirlemek ve onları pazara çıkarmanın yollarını bulabilmeleri açısından, üniversite öğrencilerinin girişimcilik eğilimlerinin saptanması öne sürülmüştür.

Günümüzde eğitim kurumlarının daha üniversite aşamasına gelmeden bireylerin girişimcilik eğilimlerini oluşturmada ciddi ve planlı bir misyon üstlendikleri görülmektedir. Bugün ilköğretim müfredatı içerisinde bağımsız iş yapabilme konusunda çocukları cesaretlendirecek ve bilinçlendirecek uygulamalar yer almaktadır.Üniversitelerde mesleki akademik bilgiler yanında, yeni iş fırsatları ve sahaları açma konusunda bireylere eğitimler verilmekte, ön lisans, lisans ve lisansüstü programlara girişimcilik dersleri konulmaktadır (Börü, 2006).

\section{Girişimcilik Eğitimi}

Küresel dünyada nitelikli insan gücü ihtiyacı, üretim sektöründe rekabetin hızla artması ve diğer pek çok faktör girişimci bireylerin önemini daha da arttırmış, dolayısıyla ülkelerin girişimci bireyler yetiştirmesini zorunlu hale getirerek girişimcilik eğitiminin devlet politikası haline gelmesine sebep olmuştur (Ulucan, 2015; Yelkikalan, 2010).

Girişimci birey yetiştirmenin temeli, eğitimden geçmektedir. Eğitim; ülke kalkınmasına artısı olan girişimci bireye yarar sağlamasının yanında, toplumsal alanda yarattığ etki sebebiyle de önemli bir unsur olarak karşımıza çıkmaktadır. Eğitim seviyesi arttıkça verimliliğin arttığı, gelir dağılımının daha adil olduğu, demokrasinin arttığı ve suç oranında azalma yaşandığı görülmektedir (Ulucan, 2015).

Literatürde girişimcilik eğitiminin farklı şekillerde birçok tanımı bulunmaktadır. Ayrıca girişimcilik eğitiminin nasıl ve ne şekilde olması gerektiği hususunda ortak bir model bulunmamaktadir. Örneğin, Dugassa (2012) girişimcilik eğitiminin öğrencilerin girişimci olma yolunda motivasyonunu arttırdığını belirtmektedir. Aynı çalışmada girişimcilik eğitimi alan öğrencilerin girişimcilik eğitimi almayan öğrencilere göre daha fazla girişimci olma niyetine sahip olduklarını belirtmektedir. Uygulanan girişimcilik eğitimi yoluyla girişimciliği bir kariyer seçeneği olarak gören öğrencilere yönelik çevresindeki yakın kişilerin tutumları da örneğin, yakın arkadaş ve ailenin tutumu gibi olumlu yönde değiştiği görülmüştür (Tessema Gerba, 2012). Hatta öğrencilere arkadaşları, aile elemanları ve kredi kuruluşları tarafından giderek artan bir seviyede destek ortamı oluşmaktadır. Bundan dolayı girişimcilik eğitimi, öğrencileri geleneksel bir kariyer için hazırlayan geleneksel eğitim programlarına karşı olarak, girişimcilik için gerekli olan bilgi, beceri, tutum ve davranışları kazanmasında önemli bir politika aracı haline gelmiştir. Bu durum girişimcilik becerilerinin öğretilebileceği varsayımına dayanmaktadır.

Girişimcilik eğitiminin girişimciliği belirleyen faktörler açısından önemli olduğu ilgili alan uzmanlarınca (Balaban ve Özdemir, 2008; Berglund ve Wennberg, 2006; Bernstein, 2011; Patır ve Karahan, 2010; Souitaris ve ark., 2007; Tağraf ve Halis, 2008; Volkmann, 2004) giderek daha sik vurgulanmakta, girişimcilik üzerine alınan eğitimin gelecekte başarılı bir girişimci olma şansını artırdığı, girişimciliğe yönelik anlayış ve farkındalığı geliştirerek bilgi düzeyini yükselttiği, olumlu tutum ve eğilimi teşvik ettiği ifade edilmekte ve girişimci doğulmadığ 1 , girişimci olunduğu anlayışı öne çıkarılmaktadır (Boz ve ark.,2013). Adı geçen çalışmalarda genç girişimci adaylarda girişimciliğe karşı olumlu tutum, eğilim ve davranış geliştirmede girişimcilik eğitiminin önem taşıdığı, gençlerdeki girişimcilik potansiyelini ortaya çıkarmaya destek sağladığı 1 ve kendi işlerini kurmaya onları teşvik ettiği görüşleri dikkat çekmektedir.

Tüm bu araştırma sonuçları ve bu araştırmadan elde edilen sonuçlar, girişimcilik eğilimlerinin geliştirilmesinde erken yaşlardan başlayarak çeşitli eğitim seviyelerinde ve türde sağlanacak girişimcilik eğitimlerinin önemine işaret etmesi açısından çarpıcıdır.

\section{MATERYAL ve YÖNTEM}

\section{Materyal}

$\mathrm{Bu}$ çalışma, Ondokuz Mayıs Üniversitesi Ziraat Fakültesi Girişimcilik dersi alan öğrencilerin demografik özellikleri ekseninde kişilik özelliklerinin girişimcilik faaliyeti üzerindeki etkisini ortaya koymaya çalışmaktadır. Araştırmanın evreni Ondokuz Mayıs Üniversitesi Ziraat Fakültesi girişimcilik dersini alan son sınıf öğrencileri ile sinırlıdır. Araştırmanın örneklemini ise Ziraat Fakültesinde eğitim gören 76 son sinıf lisans öğrencisi oluşturmaktadır. Bu araştırma demografik özellikler, girişimcilik eğilimi ve girişimcilik eğitimi adı altında incelenmiştir.

Araştırma, analize konu olan öğrencilerin girişimcilik eğilimlerinin belirlenmesi ve kişilik özelliklerinin girişimcilik eğilimleri üzerinde ne gibi yansımalarının olacağ 1 açısından önem arz etmektedir. $\mathrm{Bu}$ araştırmanın hem gelecekte yapılacak çalışmalara, 
hem de girişimcilik dersini alan öğrenciler ile almayan öğrencilerin girişimcilik eğilimlerinin belirlenmesi noktasında önemli katkılar sunacağı düşünülmektedir. Elde edilen bulgulardan yola çıkılarak öğrencilerin girişimcilik kişilik özellikleri ile girişimcilik faaliyetleri arasında ilişki olup olmadığ tespit edilmeye çalışılmıştır. Ayrıca öğrencilerin demografik özellikleri de incelenerek yüzde ve frekans tablolarıyla sonuçlar desteklenmiştir.

\section{Yöntem}

Araştırmanın yöntemi ve önsavları

Bu araştırma, yöntem açısından nicel, amacı açısından ise tanımlayıcı araştırma özelliğine sahiptir. Araştırmada öğrencilerin aldıkları girişimcilik eğitimini gözlem ve test yoluyla nesnel bir şekilde ölçmek ve sayısal verilerle açıklamak amaçlandığından, nicel araştırmaya örnek gösterilebilir. $\mathrm{Bu}$ araştırma türü belirli bir yapı içindeki ilişkilerin incelenmesine yaramaktadır. Tanımlayıcı araştırmaların temel amacı; olguların, nesnelerin, insanların, grupların veya örgütlerin özelliklerini ortaya çıkarmaktır. Tanımlayıcı araştırmalar ile kim, ne, ne zaman, nerede ve nasıl soruları yardımıyla bir durumun ya da olgunun ayrıntılı resmi ortaya konulmaya çalışmaktadır (Gürbüz ve Şahin, 2016).

\section{Araştırmanın evreni ve örneklemi}

Çalışmanın evrenini Ondokuz Mayıs Üniversitesi Ziraat Fakültesi'nde okuyan ve girişimcilik dersini alan son sınıf öğrencileri oluşturmaktadır. Araştırmanın örneklemini ise bu bölümlerde öğrenim gören ve tam sayım yöntemiyle seçilmiş 76 öğrenci oluşturmaktadır. Tam sayım yöntemi; bir araştırma kapsamında, kitledeki tüm birimlerine ulaşılarak istenen bilginin elde edilmesi işlemidir. Bunun yapılabilmesi için incelenecek kitlenin büyüklüğünün, belirlenen maliyet ve zaman gibi kısitlara uygun olması gerekir. Gelişen teknoloji ile birlikte bu tür tam sayımlar daha kolay yapılabilir hale gelmiştir (Balce ve Demir, 2007).

\section{Araștırmanın sınırlılıkları}

Çalışmanın örneklemini, 2017-2018 öğretim yılı güz döneminde Ondokuz Mayıs Üniversitesi Ziraat Fakültesinde okuyan ve girişimcilik dersini alan 76 son sınıf öğrenci oluşturmaktadır. Örneklemi öğrenciler oluşturduğu için, araştırmanın sonuçları örneklemin nitelikleri ile sinırlıdır. Elde edilen verilerin sadece bir üniversiteyi kapsaması ve verilerin tek fakülteden elde edilmiş olması ve araştırmanın en önemli kısıtlarından birini oluşturmaktadır.

\section{Araştırmada kullanılan soru formu}

Araştırmada veri toplama aracı olarak nicel araştırma yöntemlerinden anket tercih edilmiştir. Araştırmada kullanılan anket formu üç bölümden oluşmaktadır. Birinci bölüm, ankete katılan kişilerin demografik özelliklerin belirlenmesine yönelik 11 sorudan oluşmaktadır. İkinci bölümde ankete katılan Ziraat Fakültesi öğrencilerinin girişimci kişilik özellikleri ve girişimcilik faaliyetlerini tespit etmek amaciyla 5'li Likert tipi ölçeğe göre düzenlenmiş (1-Kesinlikle Katılmiyorum - 5-Kesinlikle Katılıyorum) olup 36 ifadeden oluşmaktadır. Araştırmada kullanılan girişimcilik eğilimi ölçeğinin oluşturulmasında Hisrich ve Peters, (1973) ve Koh, (1996)'nın çalışmalarından yararlanılmıştır. Anketin üçüncü bölümünde ise girişimcilik eğitimi ile ilgili sorular bulunmaktadır. Öğrencilere aldıkları dersin fayda sağlayıp sağlamadığını tespit etmek amacıyla çoktan seçmeli ve açık uçlu 36 soru yöneltilmiştir. Bu bölümdeki sorular ise Demiryürek, (2015) ve Demiryürek, (2016) tarafından geliştirilmiş olan girişimcilik eğitimi değerlendirme ve OMÜ girişimcilik anket formlarından oluşmaktadır.

Araştırmanın ilk evresinde girişimcilik alanında uzman olan 11 kişi ile anketin ön testi yapılmış, uzmanların olumlu geri bildirimleri sonucu ankete son şekil verilmiştir. Anket uygulaması 76 öğrenci ile yüz yüze gerçekleştirilmiştir. Anketlerin tamamı geri dönmüş, değerlendirmeler bu anket formları üzerinden yapılmıştır.

Anket çalışması 3 Alt boyutta olup toplam 85 soruyu içermektedir. Araştırmanın ana materyalini 76 öğrenci ile görüşülerek yapılan anketlerden elde edilen birincil veriler oluşmaktadır. Anket sorularının belirlenmesinde konuyla ilgisi olan ve daha önce gerçekleştirilmiş çalışmalar esas alınmıştır. Çalışmada kategorisel veriler kullanıldığı için girişimcilik özellikleri ve girişimcilik faaliyeti ölçekleri arasındaki ilişkiyi bulabilmek amacıyla Pearson Korelâsyon analizi yapılmıştır.

\section{Analiz yöntemleri}

Çalışmanın amacına uygun olarak anketlerden elde edilen verilerin değerlendirilmesinde tanımlayıcı istatistikler ve pearson korelasyon katsayısı gibi farklı istatistiksel analiz tekniklerinden yararlanılmıştır. Tanımlayıcı istatistik, bir gruba ait belirli değişkenlerin değerleri hakkında bilgilerin özetleyen ölçütlerdir. Kendi arasında merkezi eğilim ölçütleri, yayılma ölçütleri ve dağılımın şekil ölçütleri şeklinde sinıflandırılmaktadır (Miran, 2013).

\section{ARAŞTIRMA BULGULARI}

\section{Katılımcıların Demografik Özellikleri}

Cinsiyet değişkeni ile ilgili Çizelge $1^{‘}$ de özetlenen bilgilere göre, araştırmaya katılan 76 öğrencinin \%57.9'unun erkek, \%42.1'inin kadın olduğu görülmektedir. 
Çizelge 1. Demografik özellikler

\begin{tabular}{|c|c|c|}
\hline Cinsiyet & Sayı & $\%$ \\
\hline Kadın & 32 & 42.1 \\
\hline Erkek & 44 & 57.9 \\
\hline Toplam & 76 & 100 \\
\hline Bölgeler & Sayı & $\%$ \\
\hline Marmara Bölgesi & 3 & 3.94 \\
\hline Ege Bölgesi & 2 & 2.63 \\
\hline Akdeniz Bölgesi & 3 & 3.94 \\
\hline Karadeniz Bölgesi & 56 & 73.68 \\
\hline$\dot{I}_{c ̧}$ Anadolu Bölgesi & 7 & 9.21 \\
\hline Doğu Anadolu Bölgesi & 1 & 1.31 \\
\hline Güneydoğu Anadolu Bölgesi & 3 & 3.94 \\
\hline Yurtdış & 1 & 1.31 \\
\hline Toplam & 76 & 100 \\
\hline İkametgâh Şekilleri & Sayı & $\%$ \\
\hline$\dot{I l}$ & 33 & 43.4 \\
\hline İlçe & 30 & 39.5 \\
\hline Kasaba & 1 & 1.3 \\
\hline Köy & 12 & 15.8 \\
\hline Toplam & 76 & 100 \\
\hline Meslekler (Anne) & Sayı & $\%$ \\
\hline$E_{V}$ hanımı & 68 & 89.5 \\
\hline Memur & 3 & 3.9 \\
\hline$\dot{I}_{s ̧ c ̧ i}$ & 1 & 1.3 \\
\hline Çiftçi & 1 & 1.3 \\
\hline Emekli & 2 & 2.6 \\
\hline Öğretmen & 1 & 1.3 \\
\hline Toplam & 76 & 100 \\
\hline Meslekler (Baba) & Sayı & $\%$ \\
\hline Memur & 7 & 9.2 \\
\hline$\dot{I}_{s ̧ \zeta i} i$ & 7 & 9.2 \\
\hline Ciftçi & 15 & 19.7 \\
\hline Emekli & 27 & 35.5 \\
\hline Serbest meslek & 3 & 3.9 \\
\hline Esnaf & 13 & 17.1 \\
\hline Diğger & 4 & 5.2 \\
\hline Toplam & 76 & 100 \\
\hline Aile ortamı & Sayı & $\%$ \\
\hline Serbest & 6 & 7.9 \\
\hline Kontrollü & 29 & 38.2 \\
\hline Güvene dayalı serbest & 41 & 53.9 \\
\hline Toplam & 76 & 100 \\
\hline
\end{tabular}

Buna göre ankete katılan erkek öğrenciler örneklemin çoğunluğunu oluşturmaktadır. Araştırmaya katılan 76 ögrrencinin bölgeler ekseninde doğum yerleri ile ilgili, elde edilen bulgulardan yola çıkılarak bölge bazında bir değerlendirme yapıldığında, öğrencilerin \%73.68'inin Karadeniz bölgesinde yaşadıkları tespit edilmiştir. Ankete katılan öğrencilerin doğum yerleri dikkate alındığında \%73.68 gibi büyük bir çoğunluğunun normal dönemlerde Karadeniz Bölgesi’nde yaşadıkları görülmektedir. Katılımcıların \%43.4'ünün il merkezinde, \%1.3'inin ise kasabada ikamet ettikleri görülmektedir.

Araştırmaya katılan öğrencilerin annelerinin meslekleri incelendiğinde \%89.5'inin ev hanımı olduğu bulgusuna ulaşılmıştır. Benzer şekilde öğrencilerin baba mesleklerine verdikleri yanıtlar incelendiğinde, \%35.5'inin emekli olduğu ortaya çlkmaktadır. Araştırmaya katılan öğrencilerin aile bireylerinin meslek durumları analiz edildiğinde, annenin mesleğinin büyük oranda ev hanımı, babanın mesleğinin emekli, çiftçi ve esnaf şeklinde sıralandığı, kardeşlerin ise meslek durumlarının çoğunlukla diğer meslek grupları ve memur oldukları görülmektedir.

Araştırmaya katılan 76 öğrencinin \%53,9'unun yetiştirildiği aile ortamının güvene dayalı serbest, \%7.9'unun ise serbest aile ortamına sahip oldukları tespit edilmiştir.

\section{Geçerlilik ve Güvenilirlik}

Çizelge 2'ye bakıldığında çalışmada kullanılan ölçeğin güvenilirliğini test etmek için Cronbach's Alpha (a) katsayısı kullanılmıştır. Bu katsayı, toplam puanlar üzerine kurulu likert türü ölçeklerin güvenilirliklerinin hesaplanmasında sıklıkla kullanılmaktadır (Ongun ve ark., 2017). Cronbach's Alpha katsayısına bağlı olarak ölçeğin güvenilirliği, literatürde genel kabul gördüğü şekliyle (Kayış, 2009; Alpar, 2010; Özdamar, 1999; Yaşar, 2014; Kalaycı, 2008) göre, Cronbach's Alpha katsayısına bağlı olarak ölçeğin güvenilirliği aşağıdaki gibi yorumlanmaktadır: $0,61<\alpha<0,80$ olduğu zaman ölçek orta düzeyde güvenilir olduğu yorumunu yapabiliriz. Sosyal bilimlerde yapılan çalışmalarda (a) katsayısının bu aralıkda çıkması ise yeterli bulunmaktadır.

Çizelge 2. Güvenirliğe ilişkin bulgular

\begin{tabular}{lc}
\hline Ölçekler & Cronbach-Alpha $(\alpha)$ \\
\hline Girişimcilik Özellikleri & 0.68 \\
Girişimcilik Faaliyetleri & 0.72 \\
\hline
\end{tabular}

Araştırma Hipotezinin Test Edilmesi

Çizelge 3’te görüldüğü gibi; girişimcilik özellikleri ile girişimcilik faaliyeti arasında pozitif ve anlamlı bir ilişkinin olduğu görülmektedir. Araştırmanın amacında öğrencilerin girişimcilik eğilimlerini aldıkları ders sonucunda tespit etmek için 5'li likert 
tipi girişimcilik özellikleri ve girişimcilik faaliyetleri ile ilgili alt boyutlu ölçekler oluşturulmuştur. $\mathrm{Bu}$ ölçeklerden girişimcilik faaliyetiyle ilgili öğrencilerin düşüncelerini daha net ifade edebilmeleri için olumlu ruh hali, ilgi odağı olmaktan mutluluk duyması, inandığı düşünceyi sonuna kadar savunması, hislerine güven, geleceğe yönelik hedefinin bulunması ile ilgili 15 maddelik bir ölçek oluşturulmuştur. Bu ifadeler 1'den 5'e kadar numaralandırılmış kesinlikle katılıyorum ve kesinlikle katılmıyorum şeklinde öğrencilere seçenekler sunulmuştur. Daha sonra toplam skor yoluna başvurulmuştur.

Çizelge 3. Girişimcilik özellikleri ile giriş̧imcilik faaliyeti ilişkisi arasındaki korelâsyon analizi

\begin{tabular}{|c|c|c|c|}
\hline & & $\begin{array}{l}\text { Girișimci } \\
\text { özellikleri }\end{array}$ & $\begin{array}{c}\text { Girişimcilik } \\
\text { faaliyeti }\end{array}$ \\
\hline \multirow{3}{*}{$\begin{array}{l}\text { Girişsimci } \\
\text { özellikleri }\end{array}$} & $\begin{array}{c}\text { Pearson } \\
\text { Correlation }\end{array}$ & 1 & $.654^{* *}$ \\
\hline & $\begin{array}{l}\text { Sig. (2- } \\
\text { tailed) }\end{array}$ & & .000 \\
\hline & $\mathrm{N}$ & 76 & 76 \\
\hline \multirow{3}{*}{$\begin{array}{l}\text { Girişimci } \\
\text { faaliyeti }\end{array}$} & $\begin{array}{c}\text { Pearson } \\
\text { Correlation }\end{array}$ & $.654^{* *}$ & 1 \\
\hline & $\begin{array}{l}\text { Sig. }\left(2^{-}\right. \\
\text {tailed) }\end{array}$ & .000 & \\
\hline & $\mathrm{N}$ & 76 & 76 \\
\hline
\end{tabular}

**Korelasyon 0.01 seviyesinde anlamlıdır.

Yine aynı şekilde öğrencilerin girişimcilik alanında kişisel özellikleriyle ilgili 21 alt boyutlu ölçekde bulunan ifadelerde 1'den 5'e kadar numaralandırılmış; kesinlikle katılıyorum, katılıyorum, kararsızım, katılmıyorum ve kesinlikle katılmıyorum şeklinde öğrencilere seçenekler sunulmuştur. Daha sonra toplam skor yoluna başvurularak pearson korelasyon katsayısını hesaplamamız için ölçeğin güvenilirlik analizi yapılmıştır, Cesur, ikna kabiliyeti yüksek, liderlik özelliğine sahip olma, üretkenlik, yaratıcılık, meraklı olma, rekabet etme, güvenilir olma, hirslı bir yapıya sahip olma, dürüst vb. girişimci kişilik özelliklerine sahip olup olmamaları ile ilgili maddeler ve girişimci bir kişide olması gereken başlıca sebebler belirtilmektedir.

Ziraat fakültesi son sınıfta öğrenim gören öğrencilerin girişimcilik özellikleri ile girişimcilik faaliyeti arasında pozitif ve anlamlı bir ilişkinin olduğu görülmektedir. Öğrencilerin inandıkları düşünceleri savunmaları, kuracağı bir işte başarısız bile olsa hatalarından ders alıp yeni bir başlangıç yapma durumları arttıkça kendilerine güvenleri, geleceğe yönelik hedefleri, herhangi olumsuz bir durum karşısında görüşlerini net olarak ifade etmeleri de ortaya çıkan sonuçlardan biridir $(r=0,654, p<0.01)$. Bu sonuçlara göre; araştırmaya katılan öğrencilerin girişimcilik özellikleri arttıkça girişimcilik faaliyetinin de arttığ̣ söylenebilir.

Diğer bir ifadeyle de girişimcilik özellikleri taşıyan son sınıf öğrencilerinin aynı zamanda önemli düzeyde girişimcilik alanındaki faaliyetlere yatkın olma özelliğine sahip oldukları söylenebilir. Bu sonuçlar doğrultusunda; H0 hipotezi reddedilmiş olup, H1 hipotezi kabul edilmiştir (Çizelge 3).

\section{SONUÇ ve ÖNERİLER}

$\mathrm{Bu}$ çalışmada, öğrencilerin girişimcilik eğilimleri Ondokuz Mayıs Üniversitesi Ziraat Fakültesi ekseninde ele alınmıştır. $\mathrm{Bu}$ çalışmayla birlikte girişimcilik dersi alan üniversite öğrencilerinin girişimcilik eğilimlerinin belirlenmesi amaçlanmaktadır. $\mathrm{Bu}$ temel amacı gerçekleştirebilmek için hedeflenen alt amaçlar, ögrrencilerin sosyal ve ekonomik özelliklerini belirlemek, öğrencilerin girişimcilik eğitimleri ile ilgili genel bakış açılarını ortaya koymak ve aldıkları girişimcilik eğitimlerinin bu eğilim üzerindeki etkilerini belirlemek, öğrencilerin iş kurmaları ve kurdukları işte başarılı olmaları için tercih ettikleri unsurları belirlemek, öğrencilerin girişimcilik özelliklerimi ortaya koymaktır. Aynı zamanda bu çalışmada girişimcilik eğitimiyle birlikte yenilikçi, risk alma eğilimi, kendine güven, başarı ihtiyacı, belirsizliğe karşı tolerans, kontrol odağı gibi kişilik özellikleri öğretilerek bu yönde öğrencilerde var olan girişimcilik potansiyelinin ortaya çıkarılması amaçlanmaktadır.

Elde edilen bulgular değerlendirildiğinde, girişimciliği, belli bir kalıba sığdırmanın yanlış olduğunu söylenebilir. Bu çalışmadan ve literatür taramasından elde edilen sonuçlar incelendiğinde, girişimcilerin kendine güvenen, risk alabilen ve farklılığ koymaktadır. $\mathrm{Bu}$ noktada girişimcilik faaliyetinde bulunmak ve kendini ispatlamak isteyen kişinin ekibini çok iyi kurması gerekmektedir. Girişimci adayı Ziraat Fakültesi öğrencilerinin, toplum içerisindeki bireylerin yaşamları sürdürmek için her şeyi aile fertlerinden ya da devletten beklemek yerine kendine güvenen, başarısını kendi iş faaliyetinde arayan, kendilerini yetiştirecek bir eğitim sistemine her zaman ihtiyaç duyduklarını belirtmektedirler.

Girişimcilik faaliyetinde başarı elde edebilmek için toplum içerisinde konuşabilen, özgüveni yüksek, başkalarına fikirlerini kolayca aktarabilen ve özgün düşünce yapısına sahip öğrencilerin yetişmesi önemli görülmektedir. $\mathrm{Bu}$ durumun gerçekleşebilmesi ise verilen eğitimin niteliğine bağlıdır. Girişimcilik alanında bu tür çalışmalar yapılırken aynı zamanda düşük girişimcilik düzeyinde yer alan öğrencilerin de eğitim çalışmalarına katılmaları sağlanabilir. Ayıca girişimcilik düzeylerinin belirlenmesine yönelik yapılan eğitim çalışmalarına öğrencilerin bilgi, tutum 
ve uygulama durumları da dâhil edilebilir. Girişimcilik alanında kendisini kantlamak isteyen kişinin, ekibini iyi kurabilmesi önemli bir hususdur. Tabii ki de tek başına bir kişinin başarısıda yeterli olmamaktadır. Çünkü belli bir noktadan sonra her şeyi kendi başına yapmak mümkün olmayabilir.

Ülkenin gençlerine düşen önemli görevler vardır. Öncelikle yapacakları işi çok iyi bilmeleri ve çalışkan olmaları gerekmektedir. Yeterince bilgi sahibi olmalılardır. Bunların yanında yaptıkları işi sevmeleri ve bu işi dürüst bir şekilde sürdürmelidirler. Bunları yapınca başarı hemen arkasından gelmeyecektir. Belki hedeflerine giden yollarda, birçok olumsuzlukla karşılaşacaklar ama başarısızlık her zaman, bir sonraki denemeler için alınan iyi bir derstir diyebiliriz. $\mathrm{Bu}$ yüzden cesaret ve sabrı kendileri içinde çok iyi yönetmelidirler. Hızlı kararlar alınmalı ve bu kararlar alınırken aceleci davranılmamalıdır.

Girişimci adayı üniversite öğrencileri eğer dünya standartlarında en iyi olmak istiyorlarsa, iyi bir yabancı dile hâkim olmaları, hatta tek bir tanesiyle de sinırlı kalmamaları gerekmektedir. Mezun oldukdan sonra kendilerini eğitim alanında daha da bilgili hale getirmekten ve geliştirmekten kaçınmamalıdırlar. Girişimcilik eğiliminin belirlenmesi, potansiyel girişimcilik özelliğine sahip olanların doğru yönlendirilmesi ve iş hayatına kazandırılması ancak girişimcilerin psikolojik ve demografik faktörler ile anlamlı bir ilişsi içerisinde olmasıyla gerçekleşebilir.

$\mathrm{Bu}$ çalışma elde ettiği sonuçlar ile literatürde, üniversite öğrencilerinin girişimcilik eğilimlerinin belirlenmesi açısından önemli bir yer edinmiştir. Samsun ili Ondokuz Mayıs Üniversitesi Ziraat Fakültesi'nde uygulanmış olan araştırma, bu konuda diğer üniversitelere ya da farklı fakültelerde yapılacak olan çalışmalara örnek olabilecektir. Ayrıca bu çalışma girişimcilik konusuyla ilgilenen akademisyenler ve kamu kurum ve kuruluşlarının oluşturacağı politikalar üzerinde de etkili olacaktır.

\section{KAYNAKLAR}

Akkoç İ, Çalışkan A, Turunç Ö 2012. "Gelişim Rasyonel Alt Kültürlerinin Girişimci Davranışa Etkisi: Algılanan Cevresel Belirsizliğin Aracılık Rolü”, Anadolu Üniversitesi Sosyal Bilimler Dergisi, 12(4): 65-83.

Akyüz Y 2013.“Üniversite Öğrencilerinin KOSGEB Desteklerine Bakış Açıları ve Girişimcilik Eğilimleri Üzerine Bir Araştırma: Uşak Üniversitesi Örneği”, Uşak Üniversitesi Sosyal Bilimler Dergisi, 6(3): 80-98.

Alpar R Geçerlilik ve Güvenilirlik. Uygulamalı İstatistik ve Geçerlilik Güvenilirlik.2010.1. Baskı, Ankara: Detay Yayıncılık. s.316-66.

Arıkan S 2008. Girişimcilik: Temel Kavramlar ve Bazı Güncel Konular. Siyasal Kitabevi. 4.Baskı.
Ataç N 1998. Diyelim /Söz Arasında, İstanbul, Yapı Kredi Yayınları.

Balaban Ö, Özdemir Y 2008. Girişimcilik Eğitiminin Girişimcilik Eğilimi Üzerindeki Etkisi: Sakarya Üniversitesi İIBF Örneği. Girişimcilik ve Kalkınma Dergisi, 3(2):133-147.

Balce AO, Demir S 2007, İstatistik Ders Notları, Pamukkale Üniversitesi İktisadi ve İdari Bilimler Fakültesi, Ekonometri Bölümü, Denizli.

Berglund H, Wennberg K 2006. Creativity among Entrepreneurship Students: Comparing Engineering and Business Education, International Journal of Continuing Engineering Education and Life-long Learning, 16 (5): 366-79.

Bernstein A 2011. Nature vs Nurture: Who is Interested in Entrepreneurship Education. A Study of Bussiness and Technology Undergraduates Based on Social Cognitive Career Theory. The George Washington University, PHD.

Bird B 1989. Entrepreneurial Behavior, Glenview, IL: Scott, Foresman

Boz M, Tükeltürk ŞA 2013.“Girişimcilik Eğitiminin Öğrencilerin Girişimcilik Eğilimine Etkisi: Üniversite Öğrencileri Üzerine Bir Araştırma", Uluslararası Girişimcilik ve Kariyer Sempozyumu Bildiriler Kitabı, 1-3 Kasım, Muğla, 271-292.

Börü D 2006. Girişimcilik Eğilimi Marmara Üniversitesi İşletme Bölümü Öğrencileri Üzerine Bir Araştırma. Yayın No.733, İstanbul: Marmara Üniversitesi.

Dugassa TG 2012. The context of entrepreneurship education in Ethiopian universities. Management Research Review, 35(3): 225-244.

Dündar S, Ağca V 2007. "Afyon Kocatepe Üniversitesi Lisans Öğrencilerinin Girişimcilik Özelliklerinin İncelenmesine İlişkin Ampirik Bir Çalışma”, H.Ü. İktisadi ve İdari Bilimler Fakültesi Dergisi, 25(1):121-142.

Güney S 2008. Girişimcilik Temel Kavramlar ve Bazı Güncel Konular. Genişletilmiş 3. Baskı. Siyasal Kitabevi, Ankara.

Gürbüz S, Şahin F 2016. Sosyal Bilimlerde Araştırma Yöntemleri Felsefe-Yöntem-Analiz. Seçkin Yayıncılık, Ankara.

Greenspan A, Rosan RM 2006. The Role of Universities Today: Critical Partners in Economic Development and Global Competitiveness.

Hisrich D, Peters MP 1992. Entrepreneurship Starting, Developing and Managing A New Enterprise, Irwin, Boston.

Hisrich RD, Peters MP 1998. Entrepreneurship. New York: Irwin Mc Graw Hill.

Kalaycı Ş 2008. SPSS Uygulamalı Çok Değişkenli İstatistik Teknik . Ankara: Asil Yayın Dağıtım Ltd. Şti.

Kayış A 2009. Güvenirlik Analizi. Ş. Kalaycı (Ed), SPSS Uygulamalı Çok Değişkenli Istatistik Teknikleri. (403-419). Ankara: Asil Yayıncılık. 
Koh HC 1996. "Testing Hypotheses of Entrepreneurial Characteristics: A Study of Hong Kong MBA Students", Journal of Managerial Psychology, 11(3): $12-25$.

Korkmaz O 2012. "Üniversite Öğrencilerinin Girişimcilik Eğilimlerini Belirlemeye Yönelik Bir Araştırma: Bülent Ecevit Üniversitesi Örneği”, Afyon Kocatepe Üniversitesi İ.İ.B.F. Dergisi, 14(2): 209-226.

Miran B 2013. Temel İstatistik. Ege Üniversitesi Bornova, İzmir. s: 117-156.

Mueller S, Thomas AS 2001. "Culture And Entrepreneurial Potential: A Nine Country Study Of Locus Of Control And Innovativeness", Florida International University, Miami, National Academy Of Management, Journal Of Business Venturing, 16(1): 51-75.

Muzyka D, Koning A, Churchill N 1995. "On Organization and Adaptation: Building The Entrepreneurial Corporation". European Management Journal, 13, (4): 352-365.

Ongun U, Çiçek U, Çuhadar Y 2017. Mehmet Akif Ersoy Üniversitesi'nde Öğrenim Gören Turizm Öğrencilerinin Kırsal Turizm Faaliyetlerine Katılımını Etkileyen Kısıtlayıcılar. Bilge Uluslararası Sosyal Araştırmalar Dergisi, 1 (2): 144-156.

Özdamar K 1999. Paket Programlar Ile Istatistiksel Veri Analizi, 2.Bs., Eskişehir, Kaan Kitabevi.

Özdemir L 2013. Kırgizistan-Türkiye Manas Üniversitesi Öğrencilerinin Girişimcilik Eğilimlerinin Sosyo-Demografik Özellikler Açısından Değerlendirilmesi. Süleyman Demirel Üniversitesi İktisadi ve İdari Bilimler Fakültesi Dergisi, 20 (1): 41-65.

Patır S, Karahan M 2010. Girişimcilik Eğitimi ve Üniversite Öğrencilerinin Girişimcilik Profillerinin Belirlenmesine Yönelik Bir Alan Araştırması. İşletme ve Ekonomi Araştırmaları Dergisi, 1 (2): 2744.

Schumpeter JA 1934. The Theory of Economics Development, Oxford University Press, Oxford, U.K.
Souitaris V, Zerbinati S, Al-Laham A 2007. Do Entrepreneurship Programmes Raise Entrepreneurial Intention of Science and Engineering Students. The Effect of Learning, Inspiration and Resources. Journal of Business Venturing 22 (4): 566-591.

Tağraf H, Halis M 2008. Üniversitelerdeki Girişimcilik Eğitiminin 'Girişimsel Öz Yetkinlik' Algısı Üzerindeki Etkisi: Bir Araştırma. Girişimcilik ve Kalkınma Dergisi, 3(2): 91-111.

Tessema Gerba D 2012. The context of entrepreneurship education in Ethiopian universities. Management Research Review, 35(3/4): 225-244.

Titiz T 1999. Genç Girişimcilere Öneriler. İnkılâp Kitabevi, İstanbul.

Wang CK, Wong P 2004. Entrepreneurial Interest of University Students in Singapore, Elsevier, Technovation (24): 163-172.

Ulucan S 2015. Girişimcilik Eğiliminin ve Girişimcilik Eğilimini Etkileyen Faktörlerin Analizi: Orta Öğrenimde Lise 3. ve 4. Sinıf Öğrencileri Üzerinde Bir Uygulama, Gazi Üniversitesi Sosyal Bilimler Enstitüsü, İ̧̧letme ABD, Yüksek Lisans Tezi, $157 \mathrm{~s}$.

Volkmann C 2004. Entrepreneurship Studies-An Ascending Academic Discipline in The Twenty-first Century. Higher Education in Europe. 29 (2):177185.

Yaşar M 2014. İstatistiğe Yönelik Tutum Ölçeği: Geçerlilik ve Güvenirlik Çalışması. Pamukkale Üniversitesi Eğitim Fakültesi Dergisi 36(2): 59-75.

Yelkikalan N, Akatay A, Yıldırım MH, Karadeniz Y, Köse C, Koncagül Ö, Özer E 2010. 'Dünya ve Türkiye Üniversitelerinde Girişimcilik Eğitimi: Karşılaştırmalı Bir Analiz”, KMÜ Sosyal ve Ekonomik Araştırmalar Dergisi, 12(19): 51-59.

Yılmaz E, Sünbül AM 2009. Üniversite Öğrencilerine Yönelik Girişimcilik Ölçeğinin Geliştirilmesi, Selçuk Üniversitesi Sosyal Bilimler Enstitüsü Dergisi. 21: 196-203. 